\title{
Glycosaminoglycan loss from cartilage after Anterior Cruciate Ligament rupture: influence of time since rupture and chondral injury
}

\author{
Perda de Glicosaminoglicanas da cartilagem após ruptura do ligamento cruzado \\ anterior: influência do tempo de ruptura e da lesão condral
}

Mattiello-Rosa SMG', Cintra Neto PFA', Lima GEG', Pinto KNZ², Cohen $M^{3}$, Pimentel ER

\begin{abstract}
Objective: To quantify the concentration of sulfated glycosaminoglycans (GAGs) concentration in the synovial fluid (SF) of knees with chronic anterior cruciate ligament (ACL) rupture and to identify possible associations between GAG concentration in SF and the time elapsed since rupture and degree of chondral injury. Method: Fourteen adult male subjects with total unilateral ACL rupture, which had occurred between 5 and 144 months earlier, were assessed. All subjects underwent joint aspiration; it was possible to collect SF from ten individuals. The samples were quantified to determine the GAG concentration using dimethylmethylene blue (DMMB) staining. The degree of chondral injury was macroscopically evaluated using the modified Mankin histological scale. Spearman correlation test $(p \leq 0.05)$ was used to evaluate the association between GAG concentration and chondral injury, and Pearson correlation test $(p \leq 0.05)$ was used to evaluate the association between GAG concentration and the time elapsed since rupture. Results: The GAG concentration in SF showed a mean variation of $73.84 \pm 40.75 \mu \mathrm{g} / \mathrm{ml}$, with a mean time of $40.4 \pm 40.3$ months since the rupture. There was no correlation between GAG concentration and time since the rupture $(r=-0.09, p=0.81)$. The chondral injury grades found were $0,1,4$ and 5. There was no correlation between chondral injury grade and GAG concentration in $S F(r=-0.41$, $p=0.24)$. Conclusion: After at least 5 months, the GAG concentration in SF from knees with ACL rupture is independent of the time elapsed since rupture and/or the severity of chondral injury.
\end{abstract}

Key words: glycosaminoglycans; cartilage; anterior cruciate ligament; synovial fluid; chondral injury.

\section{Resumo}

Objetivo: Quantificar a concentração de glicosaminoglicanas sulfatadas (GAGs) no líquido sinovial (LS) de joelhos com ruptura crônica do ligamento cruzado anterior (LCA) e identificar uma possível correlação entre a concentração de GAGs no LS e o tempo pós-ruptura e grau de lesão condral. Métodos: Foram avaliados 14 indivíduos adultos do sexo masculino com ruptura total unilateral do LCA, ocorrida entre cinco a 144 meses. Todos os sujeitos foram puncionados, sendo possível a coleta de LS em dez indivíduos. As amostras foram quantificadas para determinar a concentração de GAGs usando a coloração azul de dimetilmetileno, método descrito por Farndale ${ }^{21}$. O grau de lesão condral foi macroscopicamente avaliado pela escala histológica de Mankin modificada por Messner ${ }^{14}$. As correlações entre concentração de GAGs e lesão condral foram feitas pelo teste de correlação de Sperman $(p \leq 0,05)$ e a concentração de GAGs e tempo pós-ruptura pelo teste de correlação de Pearson $(p \leq 0,05)$. Resultados: Concentração de GAGs no LS apresentou variação média de $73,84 \pm 40,75 \mu \mathrm{g} / \mathrm{mL}$, sendo o tempo médio pós-ruptura de 40,4 \pm 40,3 meses. Não houve correlação entre concentração de GAGs e o tempo pós-ruptura ( $r=-0,09, p=0,81)$. Os graus de lesão condral encontrados foram de 0, 1, 4 e 5. Não houve correlação entre grau de lesão condral e a concentração de GAGs no LS $(r=-0,41, p=0,24)$. Conclusões: Após no mínimo cinco meses, a concentração de $G A G s$ no LS de joelhos com ruptura do LCA independe do tempo pós-ruptura e/ou do grau de lesão condral.

Palavras-chaves: glicosaminoglicanas; cartilagem; ligamento cruzado anterior; líquido sinovial; lesão condral.

Recebido: 30/07/07 - Revisado: 27/09/07 - Aceito: 08/11/07

${ }^{1}$ Department of Physiotherapy, Universidade Federal de São Carlos (UFSCar), São Carlos (SP), Brasil

2 Department of Morphology and Pathology, UFSCar

${ }^{3}$ Department of Orthopedics and Traumatology, Universidade Federal de São Paulo (Unifesp), São Paulo (SP), Brasil

${ }^{4}$ Department of Cell Biology, Universidade Estadual de Campinas (Unicamp), Campinas (SP), Brasil

Correspondência para: Stela MG Mattiello-Rosa, Departamento de Fisioterapia, UFSCar, São Carlos (SP), CEP 13565-905, Brasil, e-mail: stela@power.ufscar.br 


\section{Introduction : $:$.}

Rupture of the anterior cruciate ligament (ACL) is a common injury representing $70 \%$ of all ligament injuries in sports practice. In Brazil, soccer is considered as the activity that causes most injuries to this ligament ${ }^{1}$. ACL injuries bring various sequelae to the knee joint, including compromised static stability. The consequence is alterations to knee kinematics and motor function, thereby triggering joint overload and subsequent micro-injuries to the joint cartilage that lead to the onset of osteoarthritis $(\mathrm{OA})^{2}$. However, the mechanism responsible for the degeneration of the joint cartilage following ACL rupture is not well understood yet. Mechanical instability does not seem to be the only factor responsible for the development of post-traumatic OA, since biochemical disorders may also be involved ${ }^{3}$.

During the acute phase of ACL injury, the concentration of the synovial fluid (SF) increases due to the presence of macromolecules and fragments of macromolecules derived from destructive processes in the cartilage matrix. Macromolecular changes in SF content can be observed, since under normal conditions they are virtually absent ${ }^{4,6}$. Together with the ACL injury, various components of the extracellular matrix (ECM) are found in the SF, such as cartilage oligomeric matrix protein (COMP), stromelysin, proteins and proteoglycan (PG) fragments such as sulfated glycosaminoglycans (GAGs) ${ }^{7,8}$, as well as inflammatory cells, synoviocytes and free chondrocytes ${ }^{6,9}$.

Studies by Tiderius et al. ${ }^{3}$ and Dahlberg et al. ${ }^{10}$ showed increased GAG concentrations in the SF during the acute phase of ACL rupture, in comparison with fluid sampled from the knees of healthy athletes ${ }^{11}$. Moreover, Hazell et al. ${ }^{12}$ observed more than three times increases in GAGs and PGs in the SF of traumatized knees, compared to the amount found in the contralateral knee. Ratcliffe et al. ${ }^{13}$ observed increased PG fragment levels in the joint fluids during the acute phase, although the same increase was not found in patients with chronic diseases such as OA. In addition, Messner et al. ${ }^{14}$ found a normal value of $21 \mu \mathrm{g} / \mathrm{ml}$ for GAGs in the SF from control rabbit knees. However, Taskiran et al. ${ }^{15}$ analyzed the GAG concentration in the SF from control subject knees without any kind of ligament injury and found a normal value of $13.1 \mu \mathrm{g} / \mathrm{ml}$.

During the chronic phase of ACL rupture, a reduction in SF volume occurs, although some studies have reported that PG fragment concentrations remain high even during the late phase following joint trauma ${ }^{7,8,12,15,16}$. However, during the chronic phase of ACL rupture, the onset of chondral injury is expected. Thus, the GAG concentration during this phase might be related not only to the ligament injury but also to the chronic changes found in the cartilage tissue, secondary to the chondral injury. However, the GAG concentrations in chronic and acute traumatic knee injuries, and in chondral injuries, are not well known.
When searching for associations between GAG concentrations and the periods that are considered acute and chronic, we could not find a consensus among the author. Hazell et al. ${ }^{12}$ detected increased quantities of chondroitin sulfate (a type of sulfated glycosaminoglycan marker antibody) and total GAGs in patients who had suffered ACL and/or meniscal injuries up to 10 months earlier. However, Tiderius et al. ${ }^{3}$, in their analysis of subjects with ACL rupture up to 22 days earlier, found no correlation between injury duration and estimated GAG content in the joint cartilage. Taskiran et al..$^{15}$ observed both changed and unchanged GAG concentrations six months after surgical ACL reconstruction. The concentrations of PG fragments showed significant reductions until the sixth month, when the values leveled out. Even so, these values remained above control values.

GAG concentrations are also not well known in relation to the onset and degree of chondral injury following ACL rupture. An investigation by Myers et al. ${ }^{17}$ showed no associtation between the concentration of PG fragments and the degree of severity of joint cartilage injury in dogs following ACL rupture, analyzed four and eight months after the injury. However, other studies showed the opposite relationship between PG concentration in the SF and the magnitude of joint space loss seen in knee X-rays ${ }^{11,18,19}$.

Considering that GAG molecules are known to be metabolic markers for the joint cartilage, and the fact that they can be quantified and used to indicate changes in cartilage matrix homeostasis, these cartilage components can be used as markers for joint disease progression ${ }^{3,17,20}$. Therefore, the aims of the present study were to quantify GAG concentrations in knee SF in subjects with chronic ACL rupture and to identify any possible association between GAG concentrations in SF and the time since rupture and degree of chondral injury.

\section{Methods : : .}

This study included ten male patients (mean age $29 \pm$ 5.4 years) presenting total unilateral rupture of the ACL, with or without associated meniscal injury, who sought orthopedic medical assistance in the city hospital where this study was developed over a consecutive eighteen-month period and for whom surgical arthroscopic ligament reconstruction was indicated. To be included in the sample, patients had to present chronic ligament rupture, have suffered their injury at least five months earlier, and undergo arthroscopic reconstruction by a physician. Four subjects who underwent preoperative physical therapy during the last six months before SF collection, or who suffered recurrent knee sprain within 30 days before SF collection, or who had stroke and/or joint pain, as well as those for 
whom SF collection was not possible due to the small volume of synovial fluid inside the joint, were excluded from the study.

For each patient, a physical evaluation sheet was filled in before data collection, to ensure that the inclusion and exclusion criteria were met, and to ensure that the reasons for and objectives of the study were clearly understood. Patients signed an informed consent form and were given explanations as required by the Ethics Committee of the Universidade Federal de São Carlos (Protocol: 143/04) (National Health Council Resolution No. 196/96).

\section{Macroscopic Evaluation of the Joint Cartilage}

The macroscopic appearance of the lateral and medial joint surfaces of the femoral and tibial condyles of knees with ACL rupture were evaluated based on arthroscopic findings by the orthopedist in charge. The modified histological Mankin scale ${ }^{14}$ was used after sampling the SF and immediately before ligament reconstruction. The chondral injury scores were evaluated as follows: (0) normal cartilage; (1) fibrillation and surface irregularities; (2) surface irregularities and formation of pannus; (3) formation of surface fissures; (4) deep but local fissures, down to the subchondral bone; (5) large defects on the joint surface, down to exposure of the subchondral bone; (6) total loss of joint cartilage in the areas of weight-bearing unload. The score for the degree of tissue destruction was defined using the maximum score parameter from the highest degree of chondral injury (0-6 scale) found in any one of the four regions of femoral or tibial condyles.

The evaluation was conducted blindly to GAG concentration in the synovial fluid.

\section{Synovial fluid aspiration}

Synovial fluid was aspirated from the suprapatellar bursa before carrying out the ACL reconstruction surgery, for analysis. First, the injured knee was shaved on its anterolateral face and spinal anesthesia was applied. Then, the orthopedist in charge inserted a needle in the lateral region of the knee and the synovial fluid was arthroscopically collected at the time of surgery. After collection, the fluid from each subject was stored in a properly closed and labeled plastic container and the samples were quantified for volume. Then, a $3.8 \%$ sodium citrate solution was added and the samples were stored at minus $20^{\circ} \mathrm{C}$ until they were analyzed.

\section{Analysis of Sulfated Glycosaminoglycans}

The samples obtained were quantified for GAG concentration using the dimethylmethylene blue (DMMB) dye technique, in accordance with the method described by Farndale ${ }^{21}$. The SF samples were centrifuged at $8,000 \mathrm{rpm}$ for 10 minutes and the supernatant liquid was diluted ten times with $0.05 \mathrm{M}$ phosphate buffer ( $\mathrm{pH}$ 7.0). Samples of $100 \mu \mathrm{l}$ were digested with $100 \mu \mathrm{l}$ of buffer containing $2.6 \mathrm{mM}$ papain, 0.6 $\mathrm{mML}$-cysteine, $2 \mathrm{mM} \mathrm{EDTA}$, and $5 \mathrm{mM} \mathrm{NaCl}$. After incubating for two hours at $65^{\circ} \mathrm{C}$, sodium chloride was added ( final $\mathrm{NaCl}$ concentration: $0.5 \mathrm{M}$ ); the volume was completed to $250 \mu \mathrm{l}$, and an aliquot of $100 \mu \mathrm{l}$ was withdrawn. Once the sample was ready to be examined, $2.5 \mathrm{ml}$ of DMMB reagent solution was added to the material and, after a few seconds, the absorbance was measured at $\lambda=526 \mathrm{~nm}$, using a spectrophotometer.

To determine the GAG concentration, a comparison was made between the GAG concentration values measured in SF samples and the values on a standard curve that was made prior to the analysis using known concentrations of chondroitin sulfate.

\section{Statistical analysis}

Pearson correlation coefficient was used to evaluate the association between the length of time since rupture on the GAG concentration in SF, and the Spearman rank correlation coefficient was used to evaluate the relationship between chondral injury degree and GAG concentration in SF. For all statistical analyses, the significance level was set at 5\% $(\alpha=0.05)$.

\section{Results : $:$.}

All the patients with chronic ACL ruptures were in the 22 40 year age range (mean age $29.5 \pm 5.4$ years). It was possible to obtain SF by joint aspiration from 10 subjects, of whom six had their injuries in the right knee. The mean time since the rupture was $40.4 \pm 40.3$ months (range: 5 - 144 months) (Table 1).

The mean volume of aspirated SF was $4.4 \mathrm{ml} \pm 4.4 \mathrm{ml}$ (range: $0.8-12 \mathrm{ml}$ ) (Table 1). All aspirated liquids were citrus yellow in color at the time of collection. A single patient (Patient I) presented blood strands mixed with the collected liquid, but this was due to sample contamination by the needle used for collecting the material through the skin. Another four patients presented fragments or free bodies resulting from the joint cartilage injury, suspended in the fluid (data not shown). During the arthroscopy procedure, medial meniscal injury was observed in five subjects, of whom three also had lateral meniscal injury.

Absorptiometric analysis on the samples with DMMB showed that the mean GAG concentration was $73.8 \pm 40.7 \mu \mathrm{g} / \mathrm{ml}$ (range: $25.2-158.0 \mu \mathrm{g} / \mathrm{ml}$ ). The individual values are shown in Table 1. The results showed that there was no correlation 
between the GAG concentration and the time since the rupture $(\mathrm{r}=-0.09, \mathrm{p}=0.81)$ (Figure 1).

The macroscopic evaluation of the joint cartilage showed that in three patients (Patients $\mathrm{B}, \mathrm{C}$ and $\mathrm{H}$ ) no change was found on the cartilage surface, while two other patients ( $\mathrm{Pa}$ tients $\mathrm{F}$ and J) had deep local injuries. Chondral injury scores of 2, 3 and 6 were not observed in this study. There was no correlation between chondral injury degree and GAG concentration in SF $(r=-0.41, p=0.24)$ (Figure 2).

\section{Discussion $: \because$.}

The present study has shown the existence of variation in the SF volume found by joint aspiration in knees with total ACL rupture, either with or without associated meniscal injury.
Moreover, there was variation in GAG concentration in the SF from patients who suffered ACL rupture at least five months earlier and different chondral injury scores. On average, the volume of SF found in the injured joint in the present study was $4.4 \mathrm{ml}$. The synovial fluid in joint diseases may present variations in its composition and volume. The volume may be 10-20 times higher than normal values, as a result of the greater production of inflammatory exudate, which mirrors the pathological phenomenon that occurred in the joint ${ }^{22}$.

According to Fawthrop et al. ${ }^{8}$, the volume of SF present in the human knee varies from $0.2 \mathrm{ml}$ to $2 \mathrm{ml}$, and from $1 \mathrm{ml}$ to $50 \mathrm{ml}$ in subjects with OA. A study by Tiderius et al. ${ }^{3}$ showed that the mean volume of SF found in patients with acute ACL rupture was $19 \mathrm{ml}$, due to the greater joint inflammatory infiltrate present during this phase, which was higher than the volume found in our study of chronic injury.

Table 1. Characteristics of patients with anterior cruciate ligament injury*.

\begin{tabular}{|c|c|c|c|c|c|c|c|c|c|}
\hline Patients & $\begin{array}{c}\text { Age } \\
\text { (years) }\end{array}$ & $\begin{array}{l}\text { Height } \\
(\mathrm{cm})\end{array}$ & $\begin{array}{c}\text { Weight } \\
(\mathrm{kg})\end{array}$ & Injured knee & $\begin{array}{c}\text { Time since } \\
\text { ACL rupture } \\
\text { (months) }\end{array}$ & $\begin{array}{c}\text { GAGs } \\
\text { content in } \\
\text { synovial fluid } \\
(\mu \mathrm{g} / \mathrm{mL})\end{array}$ & $\begin{array}{c}\text { Synovial } \\
\text { fluid in knee } \\
(m L)\end{array}$ & $\begin{array}{c}\text { Meniscal } \\
\text { injury }{ }^{\dagger}\end{array}$ & $\begin{array}{l}\text { Chondral } \\
\text { injury score }\end{array}$ \\
\hline $\mathrm{A}$ & 24 & 164 & 64 & L & 5 & 41.0 & 9.0 & $M+L$ & 4 \\
\hline$B$ & 29 & 173 & 75 & $L$ & 6 & 96.9 & 0.8 & Absent & 0 \\
\hline C & 22 & 183 & 93 & $\mathrm{R}$ & 16 & 158.0 & 0.8 & Absent & 0 \\
\hline D & 37 & 165 & 73 & $\mathrm{R}$ & 18 & 25.2 & 12.0 & L & 4 \\
\hline$E$ & 30 & 175 & 85 & $\mathrm{R}$ & 33 & 35.3 & 2.0 & Absent & 1 \\
\hline $\mathrm{F}$ & 28 & 167 & 82 & L & 36 & 99.1 & 4.0 & $M+L$ & 5 \\
\hline$G$ & 40 & 186 & 83 & $\mathrm{R}$ & 43 & 59.2 & 11.0 & $M+L$ & 1 \\
\hline $\mathrm{H}$ & 30 & 169 & 72 & L & 47 & 105.2 & 3.0 & L & 0 \\
\hline I & 27 & 178 & 81 & $\mathrm{R}$ & 56 & 51.1 & 1.0 & $\mathrm{M}$ & 1 \\
\hline $\mathrm{J}$ & 28 & 165 & 68 & $\mathrm{R}$ & 144 & 67.3 & 1.0 & $\mathrm{M}$ & 5 \\
\hline
\end{tabular}

*For all patients, the mean \pm standard deviation values are respectively the following: age, $29.5 \pm 5.4$ years; height, $172.5 \pm 7.8 \mathrm{~cm}$; weight, $77.6 \pm 8.7 \mathrm{~kg}$; time since rupture, $40.4 \pm 40.3$ months; GAGs concentration in the SF, $73.8 \pm 40.7 \mu \mathrm{g} / \mathrm{mL}$; amount of SF present in the knee, $4.4 \pm 4.4 \mathrm{~mL}$.

${ }^{\dagger} \mathrm{M}$ : medial meniscus; L: lateral meniscus.

Chondral injury scores: (0) normal cartilage; (1) fibrillation and surface irregularities; (2) surface irregularities and formation of pannus; (3) formation of surface fissures; (4) deep, but local, fissures, down to exposure of the subchondral bone; (5) large defects on the joint surface down to exposure of the subchondral bone; (6) total loss of joint cartilage in the areas of weight unload.

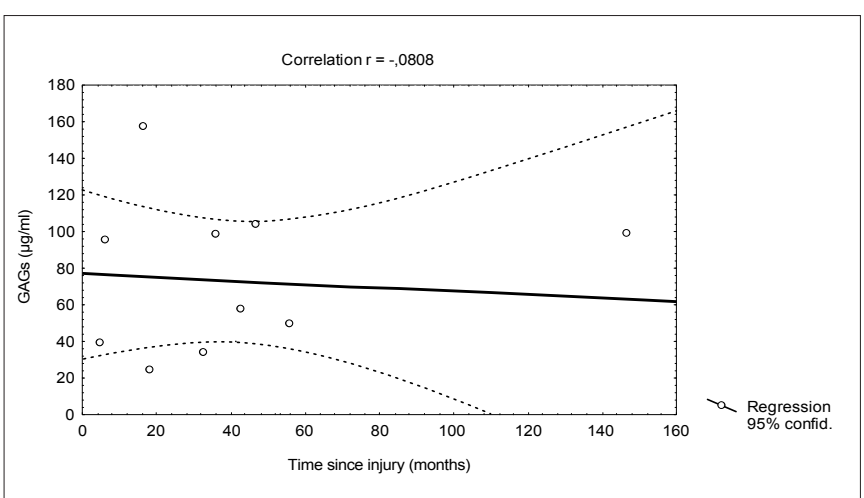

Figure 1. Concentration curve $(\mu \mathrm{g} / \mathrm{mL})$ of GAGs in the synovial fluid in ten patients with $A C L$ injury as a function of time since rupture (months) $(r=-0.0868, p<0.812)$.

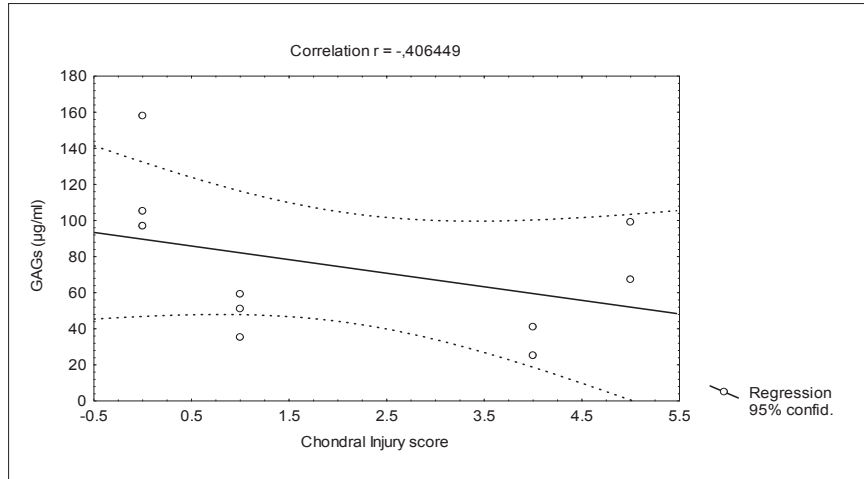

Figure 2. Concentration curve $(\mu \mathrm{g} / \mathrm{mL})$ of $\mathrm{GAGs}$ in the synovial fluid in ten patients with ACL injury as a function of chondral injury score $(r=-0,41, p=0,24)$. 
The mean GAG concentration found in the SF was $73.8 \pm 40.7$ $\mu \mathrm{g} / \mathrm{ml}$ (Table 1) in patients with chronic ACL rupture. Such values are higher than the normal levels for knees without previous joint injury that are described in the literature ${ }^{14,15}$. Few studies have found chondroitin sulfate levels in SF from the contralateral knee that were within normal values. In addition to the difficulty in obtaining SF from the contralateral joint, the use of the contralateral knee is not an advantage, since some patients with knee injury may change their gait and thus promotes abnormal loads on the contralateral knee. This would probably reduce the differences between the traumatized knee and the contralateral $\mathrm{knee}^{8,12}$ and the normal values obtained would not be reliable.

Several authors have reported increased quantities of antibodies that are chondroitin sulfate markers, as well as increased GAG concentration, in patients with chronic knee injuries. These values remained elevated for many years after the trauma and thus were able to indicate not only the progression of the injury, but also its repair process ${ }^{12,15,23}$. In our study, subjects with a minimum time since the rupture of five months were evaluated, i.e. subjects presenting chronic ligament rupture. The mean GAG concentration found in the SF was higher than the normal levels described in the literature ${ }^{14,15}$. However, there was no correlation between the GAG concentration and the length of time since the rupture, which confirms the studies by Tiderius et al. ${ }^{3}$.

Our results showed that patients whose ruptures occurred more than four years earlier (Patients I and J) still presented GAG levels that were higher than normal values, thus confirming the available data in the literature. In humans, high levels of GAGs in the SF have been noticed in association with acute ACL and meniscal injury, as well in primary and post-traumatic $\mathrm{OA}^{10,14,17,24}$. The concentration increases to a maximum one week after the trauma, thereafter reducing to a plateau level three to six months after the injury ${ }^{10,12,15,24}$. However, the concentrations of PG fragments still remain above the control values in many cases (up to four years after ligament rupture), thus indicating a possible biochemical disorder ${ }^{16,25}$.

A study by Uesaka et al. ${ }^{20}$ measured the concentration of chondroitin sulfate, and found higher values in the early stages of chondral injury. These values tended to reduce as the chondral injury advanced, thus indicating a possible inverted relationship between the concentration of this marker and the degree of joint degeneration. This confirmed the results obtained by Dahlberg et al. ${ }^{11}$, who also noticed an inverse relationship between the chondral injury score and the mean concentration of proteoglycan fragments in the SF of patients with ACL and/or meniscal injury. The reduction in proteoglycan fragment levels in the SF with increasing degree of chondral injury in OA probably results from the reduction in the amount of cartilage present in the joint ${ }^{11,20,26}$.

Although the concentrations of the markers in the synovial fluid seem to be derived from the joint cartilage, rather than from the GAGs present in the menisci and ligaments ${ }^{27}$, the results indicated that there was no correlation between the GAG concentration in the SF and the degree of chondral injury. Regardless of any associated meniscal injury, patients with ACL rupture presented a higher risk of post-traumatic chondral injury, which confirms previous studies ${ }^{18,28}$. However, the association between meniscal injury and the use of meniscectomy was considered to be the main factor responsible for the degenerative events in the joint cartilage ${ }^{29}$.

Experimental studies using OA models have shown that, immediately after the trauma, changes are noticed in the metabolic, chemical and mechanical characteristics of the matrix, prior to the onset of macroscopic or radiological changes ${ }^{18}$. The function and complex structure of the normal joint cartilage can be altered even by minor traumas ${ }^{30}$. In addition, Nakayama et al. ${ }^{31}$ reported that the difficulties in interpreting proteoglycan fragments in the synovial fluid are due not only to their molecular origin and the different tissues in the joint, but also to the fact that the clinical stage of the joint condition certainly has a different effect on each tissue. Further investigation is required to identify the origin of the proteoglycan fragments in the SF.

We believe that using different types of biological markers will make it possible to properly monitor and treat pathological conditions of the cartilage tissue. Many questions still remain regarding the GAG levels present in the synovial fluid as a form of prognosis for chondral injury. Different methods for quantifying GAGs are being studied, as well as individuals with different kinds of pathological conditions and lengths of time since their injuries.

In spite of the high incidence of ACL injuries and the large number of papers published on the progression of chondral injury secondary to ACL injuries, the number of ongoing studies investigating the levels of possible chondral injury markers such as sulfated glycosaminoglycans in chronic ACL injuries, as well as the association between these levels and the length of time since ligament injury and degree of cartilage degeneration, is still small.

\section{Conclusions : :}

The results from this study show that, after a minimum fivemonth period, the GAG concentration in the SF from knees with ACL rupture does not depend on the length of time since rupture and/or the degree of chondral. Nonetheless, it is accepted that a relationship exists between ACL injury, more pronounced presence of sulfated GAGs in the synovial fluid and chondral injury. This fact suggests that the detection of sulfated GAGs in the synovial fluid from knees with ACL injury indicates joint cartilage degradation, thereby enabling early diagnosis of chondral injury and making it possible to start an early treatment schedule and lead to a better functional prognosis for patients. 


\section{References $: \because$.}

1. Hebert S, Xavier R. Ortopedia e traumatologia: princípios e prática. Porto Alegre: Artmed; 2003.

2. Brandt KD, Myers SL, Burr D, Albrecht M. Osteoarthritic changes in canine articular cartilage, subchondral bone and synovium fitty-four months after transection of the anterior cruciate ligament. Arthritis Rheum. 1991;34:1560-70.

3. Tiderius CJ, Olsson LE, Fredrik L, Dahlberg L. Cartilage glycosaminoglycan loss in the acute phase after anterior cruciate ligament injury. Arthritis Rheum. 2005;52:120-7.

4. Martel-Pelletier J. Pathophysiology of osteoarthritis. Osteoarthritis Cartilage. 1998;6:374-6.

5. Freemont AJ, Denton J. The cytology of synovial fluid. In: Gray W, editors. Diagnostic cytology. New York: Churchill Livingstone; 1995. p. 887-98.

6. Rorvik AM, Grondahl AM. Markers of osteoarthritis: a review of the literature. Vet Surg. 1995;24:255-62.

7. Cameron M, Buchgraber A, Passler H, Vogt M, Thonar E, Fu F, et al. The natural history of the anterior cruciate ligament-deficient knee: changes in synovial fluid cytokine and keratan sulfate concentrations. Am J Sports Med. 1997;25:751-4.

8. Dalhberg L, Roos H, Saxne T, Heinegard D, Lark MW, Hoerner LA, et al. Cartilage metabolism in the injured and uninjured knee of the same patient. Ann Rheum Dis. 1994;53:823-7.

9. Fawthrop F, Hornby J, Swan A, Hutton C, Doherty M, Dieppe P. A comparison of pathological and normal synovial fluids. Br J Rheumatol. 1985;24:61-9.

10. Dahlberg L, Friden T, Roos H, Lark MW, Lohmander LS. A longitudinal study of cartilage matrix metabolism in patients with cruciate ligament rupture: synovial fluid concentration of agrecan fragments, stromelysin-1 and tissue inhibitor of metalloproteinase-1. Br J Rheumatol. 1994;33:1107-11.

11. Dahlberg L, Ryd L, Heinegard D, Lohmander LS. Proteoglycan fragments in joint fluid: influence of arthrosis and inflammation. Acta Orthop Scand. 1992;63:417-23.

12. Hazell KP, Dent C, Fairclough JA, Bayliss MT, Hardingham TE. Changes in glycosaminoglycan epitope levels in knee joint fluid following injury. Arthritis Rheum. 1995;38:953-9.

13. Ratcliffe A, Doherty M, Maini RN, Hardingham TE. Increased concentrations of proteoglycan components in the synovial fluid of patients with acute but not chronic joint disease. Ann Rheum Dis. 1998;47:826-32.

14. Messner K, Gillquist J, Bjornsson S, Lohmander LS. Proteoglycan fragments in rabbit joint fluid correlated to arthrosis stage. Acta Orthop Scand. 1993;64:312-6.

15. Taskiran E, Taskiran D, Duran T, Lok V. Articular cartilage homeostasis after anterior cruciate ligament reconstruction. Knee Surg. 1998;6:93-8.

16. Lohmander LS, Dahlberg L, Ryd L, Heinegard D, Lohmander LS. Increased levels of proteoglycan fragments in joint knee joint fluid after injury. Arthritis Rheum. 1989;32:1434-42.

17. Myers SL, Brandt KD, Albrecht ME. Synovial fluid glycosaminoglycan concentration does not correlate with severity of chondropathy or predict progression of osteoarthritis in a canine cruciate deficiency model. J Rheumatol. 2000;27:753-63.

18. Lohmander LS, Hoerrner LA, Lark MW. Metalloproteinases, tissue inhibitor, and proteoglycan fragments in knee synovial fluid in human osteoarthritis. Arthritis Rheum. 1993;36:181-9.

19. Saxne T, Heinegard D. Synovial fluid analysis of two groups of proteoglycan epitopes distinguishes early and late cartilage lesions. Arthritis Rheum. 1992;35:385-90.

20. Uesaka S, Nakayama Y, Shirai Y, Yoshihara K. Serum and synovial fluid levels of chondroitin sulfate in patients with osteoarthritis of the knee joint. J Nippon Med Sch. 2001;68:165-70.

21. FarndaleRW, ButtleDJ, BarrettAJ. Improved quantitationand discrimination of sulfated glycosaminoglycans by use of dimethylmethylene blue. Biochim et Biophys Acta. 1986;883:173-7.

22. Jones STM, Denton J, Holt PJL, Freemont AJ. Possible clearance of effect polymorphonuclear leukocytes from synovial fluid by cytophagocytic mononuclear cells: implication for pathogenesis and chronicity in inflammatory arthritis. Ann Rheum Dis. 1993;52:121-6.

23. Lohmander LS. Articular cartilage and osteoarthrosis. The release of aggrecan fragments into synovial fluid after joint injury and in osteoarthritis. The Journal of Rheumatology. 1995;22:75-7.

24. Lohmander LS, Roos H, Dahlberg L, Ryd L, Hoerner LA, Lark MW. Temporal patterns of stromelysin-1, tissue inhibitor, and proteoglycans fragments in human knee joint fluid after injury to the cruciate ligament or meniscus. J Orthop Res. 1994;12:21-8.

25. Marks PH, Donaldson MLC. Inflammatory cytokine profiles associated with chondral damage in the anterior cruciate ligament-deficient knee. Arthroscopy. 2005;21:1342-7.

26. Saxne T, Heinegard D, Wollheim FA, Pettersson H. Difference in cartilage proteoglycan level in synovial fluid in early rheumatoid arthritis and reactive arthritis. Lancet. 1985;2:127-8.

27. Shinmei M, Miyauchi S, Machida A, Miyazaki K. Quantitation of chondroitin 4-sulfate and chondroitin 6-sulfate in pathologic joint fluid. Arthritis Rheum. 1992;35:1304-8.

28. Lohmander LS. Markers of cartilage metabolism in arthrosis. A review. Acta Orthop Scand. 1991;62:623-32.

29. Christoforakis J, Pradhan R, Sanchez-Ballester J, Hunt N, Strachan RK. Is there an association between articular cartilage changes and degenerative meniscus tears? Arthroscopy. 2001;17:481-90.

30. Alford JW, Cole BJ. Cartilage restoration: basic science, historical perspective, patient evaluation, and treatment options. The American Journal of Sports Medicine. 2005;33:295-306.

31. Nakayama Y, Narita T, Mori A, Uesaka S, Miyazaki K, Ito H. The effects of age and sex on chondroitin sulfates in normal synovial fluid. Arthritis and Rheumatism. 2002;46:2105-8. 